\title{
A review of the potential effects of suspended sediment on fishes: potential dredging-related physiological, behavioral, and transgenerational implications
}

\author{
Michael E. Kjelland ${ }^{1}$ Christa M. Woodley ${ }^{1} \cdot$ Todd M. Swannack $^{1,2}$ • \\ David L. Smith ${ }^{1}$
}

Published online: 23 July 2015

(c) The Author(s) 2015. This article is published with open access at Springerlink.com

\begin{abstract}
The long-term effects of sediment exposure on aquatic organisms are poorly understood, yet it is critical for determining threshold effects and exposure limits to mitigate potential impacts with regard to population dynamics. In this paper, we present the current state of knowledge to help consolidate the breadth of information regarding total suspended solids (TSS) thresholds for aquatic species, as well as identify areas where data are lacking. More specifically, we provide the state of the science related to TSS effects on freshwater and estuarine fish including short-term (i.e., physiology and behavior) and long-term effects. Our research indicated that little attention has been given to examining long-term effects, e.g., transgenerational effects, from suspended sediments (SS) on fish populations. Understanding transgenerational effects is paramount to developing and predicting the links between fish condition, survival, populations, and communities. Survival of a local fish population to high sediment loads often translates into short-term physiological and behavioral effects; however, the ramifications of such exposure events are rarely tracked across generations. The majority of studies involving SS effects on fish have focused on exposure and mortality rates of affected fish, deposited eggs, or larvae. We developed a conceptual model that highlighted the interactions between sediment dynamics and fish populations. The model can assist in the formulation of more quantitative-based approaches for
\end{abstract}

Michael E. Kjelland

Michael.E.Kjelland@usace.army.mil

1 Environmental Laboratory, U.S. Army Engineer Research and Development Center, Vicksburg, MS 39180-6199, USA

2 Department of Biology, Texas State University, San Marcos, TX 78666, USA modeling these interactions. Future research efforts should focus on developing an understanding of whether environmental disturbances, e.g., dredging, may lead to epigenetic changes that may lead to cascade population effects, and if so, under what circumstances.

Keywords Suspended sediments - Dredging ·

Physiology $\cdot$ Behavior · Population dynamics $\cdot$ Epigenetics

\section{Introduction}

Modern commerce relies on navigable waterways to maintain commodity transport across the globe. For example, in 2013, 3,165 tons of goods were transported throughout the U.S. waterways (U.S. Water System 2015). River channel maintenance relies on frequent dredging to keep the waterways navigable. The U.S. Army Corps of Engineers (USACE) dredges, on average, over 147 million cubic yards of sediment annually. Some of the material is removed from the system and used beneficially for beach and wetland nourishment, or habitat creation, while other material may be re-deposited back into the system. Dredging is a complex activity, and its impact on aquatic ecosystems is poorly understood, particularly over long timescales. For example, species are exposed to dredgecreated suspended sediment plumes if they are in close proximity to the dredge. However, these plumes are ephemeral and vary in concentration, lessening the further away from the source. Likewise, if the species is vagile, it can choose to move away from the sediment source once exposed. Further, the sensitivity of a species can change ontogenetically, so impacts can be mitigated if a less sensitive life stage is exposed, (e.g., the fry life stage vs an adult). Most of the research in this arena has focused on 
impacts of sediment exposure on aquatic species. Notably, there have been few studies which focused exclusively on the relationship between dredging activities and population dynamics of aquatic species. In this paper, we review the current state of knowledge on sediment-fish interactions and attempt to place the work in the context of developing research tools and methods to help begin to understand the impacts of dredging on fish communities.

Sediments are particles that have been suspended, transported, and deposited by water, and are natural and important to elemental cycling in rivers, lakes, and coastal ecosystems (Nichols 1999; Beussink 2007). Suspended sediment events are important, nationally and internationally, as nutrients and contaminants fluxes occur in lakes, rivers, estuaries, coastal systems, and oceans. The rate and magnitude of SS events can be altered by factors such as changes in land use and anthropogenic activities. Suspended solids are often of two general types: inorganic and organic. Inorganic sediments can be described based on mineral composition, origin, particle shape, size, and distribution (Nichols 1999; Beussink 2007), whereas the organic component is biodegradable and varies with origin, amount, and stage of particulate organic matter (Wood 1997). Sediment transport is a function of water movement, and sediment characteristics and composition resulting in a variety of transportation modes. Bed load and suspended load are the primary transportation modes of sediment. Bed load describes sediment particles that move along the bed. Suspended load refers to the suspension of small particles (typically clays and silts $<62 \mu \mathrm{m}$ in diameter) that are carried in the water column (Waters 1995; Garcia 2008). Increases in suspended sediments loads, frequencies, and timing of events are often related directly to anthropogenic activities (e.g., vessels, navigation maintenance and construction, port and road construction, mining, agriculture, logging, and urban development), and indirectly through altered precipitation patterns, increased temperatures, and changes in hard freezes, snowpacks, and snow melts related to changing climates.

Suspended sediment concentrations or water clarity can be directly measured as total suspended sediments (TSS) in $\mathrm{mg} / \mathrm{L}$, but more frequently are indirectly measured as turbidity (Fleming et al. 2005). Turbidity is a parameter that is an expression of the optical properties in a sample, and is a measure of the light rays being scattered and absorbed rather than transmitted in straight lines through the sample. Because turbidity measurements are influenced by other compounds and organisms, the correlative relationship of TSS to nephelometric turbidity units (NTUs) is, at best, temporally and spatially explicit.

Suspended sediments can elicit a short- and long-term response from aquatic biota depending on the quantity, quality, and duration of suspended sediment exposure
(Caux et al. 1997; Newcombe 2003; Fleming et al. 2005). In 1998 , about $40 \%$ of assessed river miles in the U.S.A. had sediment stress-related issues (U.S. EPA 2000). Suspended and bedded sediment (SABS) loading imbalance in aquatic systems can be considered one of the greatest causes of impaired water quality (U.S. EPA 2003; Berry et al. 2003).

In the U.S.A., a universal measurement for SABS does not exist, nor do standard durations for SABS effects testing (Berry et al. 2003). The U.S. EPA has set the following recommendations for developing a numeric criterion for suspended solids and turbidity, i.e., "Settleable and suspended solids should not reduce the depth of the compensation point for photosynthetic activity by more than $10 \%$ from the seasonally established norm for aquatic life" (U.S. EPA 2006). However, there currently exists a wide range of turbidity criteria utilized in the U.S.A. (Berry et al. 2003). The criteria used for SABS can be numerical, narrative, a combination of both, or none at all. The U.S. EPA conducted a study of published SABS criteria in all states in 2001. Numeric SABS criteria existed in 32 of the 53 states, tribes, and territories, and the District of Columbia (U.S. EPA 2006), of which only 30 had criteria for turbidity and seven for suspended solids and five listed criteria for both turbidity and suspended solids. Criteria were in the form of exceedances over background (e.g., "not more than $10 \%$ above background" or "no more than 10 NTUs above background") or absolute values (e.g., "not greater than 100 NTU") (U.S. EPA 2006). Several states provide criteria for an averaging period (e.g., 30 days) as well as an allowed daily maximum concentration (Berry et al. 2003). Other states use exceedances over background (e.g., "not greater than 50 NTU over background", or "not more than $10 \%$ above background"), while some use absolute values (e.g., "not greater than $100 \mathrm{NTU}$ "). There are not many states that use suspended solids as a water quality criterion and values vary from 30 up to $158 \mathrm{mg} / \mathrm{L}$ (Berry et al. 2003). Importantly, both the duration (Newcombe and MacDonald 1991) and frequency (Shaw and Richardson 2001) of SAB exposures should be considered when establishing guidelines for exposure thresholds for aquatic organisms (Berry et al. 2003).

In comparison, the regulatory criteria set forth by British Columbia for the protection of aquatic life are as follows: "(1) For clear flow periods, induced turbidity should not exceed background levels by more than 8 NTU during any 24-h period (hourly sampling preferred). For sediment inputs that last between $24 \mathrm{~h}$ and 30 days (daily sampling preferred), the mean turbidity should not exceed background by more than 2 NTU. (2) For turbid flow periods, induced turbidity should not exceed the background levels by more than 8 NTU at any time when background turbidity is between 8 and 80 NTU. When background 
exceeds 80 NTU, turbidity should not be increased by more than $10 \%$ of the measured background level at any one time. (3) The clear and turbid flow periods are defined by the portion of the hydrograph when suspended sediment concentrations are low (taken to be less than 8 NTU) and relatively elevated (taken to be greater than or equal to 8 NTU), respectively" (Fleming et al. 2005).

Suspended sediments absorb heat energy thereby raising water temperatures (Ellis 1936; Reid 1961; Ryder and Pesendorfer 1989). Turbidity can reduce light transmission through the water and decrease photosynthesis by aquatic plants, consequently affecting dissolved oxygen levels (Berry et al. 2003). As noted in Coen (1995), such effects of turbidity on water quality may result in biological effects on aquatic organisms such as disruptions in migrations and spawning, movement patterns, sublethal effects (e.g., disease susceptibility, growth, and development), reduced hatching success, and direct mortality. Effects of suspended sediments on fish depend upon several factors: species, temperature at exposure time (e.g., Servizi and Martens 1991), type of suspended sediment, [i.e., particle size (Muck 2010) and angularity (e.g., Lake and Hinch 1999)] sediment contaminants (Matta et al. 1999), duration and frequency of exposure, and dose.

In this paper, we present a review of the existing literature in order to help identify the current scope of information available regarding total suspended solids thresholds for fish species. We then develop a conceptual model of the current understanding of the relationship between sediment dynamics and exposure, and fish species. We also identify areas where further research is necessary. The goal of this review is to provide the state of the science related to suspended sediments effects on freshwater and estuarine fish including short-term (i.e., physiology and behavior) and long-term effects (transgenerational).

\section{Methods}

We began our investigation using a Boolean search using Google Scholar (scholar.google.com). Given the immense amount of literature related to general search terms as "dredging and fish," we explicitly focused the search to a combination of terms: dredging, fish, physiology, behavior, and epigenetic inheritance or transgenerational.

\section{Results}

The Google Scholar search engine retrieved approximately 61,000 results related to more general search terms as "dredging and fish." The search terms of "dredging and fish and behavior" or "dredging and fish and physiology" produced about 32,800 and 19,500 citations, respectively. "Dredging and fish gametes" produced 3,050 citations, a reduction of about $95.3 \%$. Interestingly, the search phrase "dredging and fish and transgenerational" or "dredging effects and fish gametes and transgenerational" produced only 136 and 14 results, respectively, a reduction of about 99.7 and $99.9 \%$. The aforementioned results demonstrate the little attention given to examining long-term, insidious effects, such as transgenerational effects, from suspended sediments on fish populations. Understanding transgenerational effects is paramount to developing and predicting the links between fish condition, survival, populations, and communities. For example, survival of a local fish population to high sediment loads often translates into shortterm physiological and behavioral effects; however, often full ramifications of such effects are not tracked into the next generation. Presently, the majority of the studies involving suspended sediment effects on fish have focused on exposure and mortality rates of the exposed fish or deposited eggs and larvae. Accordingly, a review was conducted of more than 150 peer-reviewed papers and reports pertaining to suspended sediments, dredging, and potential effects on fish and other aquatic organisms.

\subsection{Fish behavior and movement}

In general, fish are more likely to undergo sublethal stress from suspended sediments rather than lethality because of their ability to move away from or out of an area of higher concentration to a lower concentration versus sessile or less mobile species. Therefore, it is important to understand how suspended sediments affect the behavior and physiology over both short- and long-term scales. From our review, three overarching trends appear: preference, physiological adjustment, and avoidance. The consequences of these trends can be observed in a variety of contexts, e.g., social disruption, migratory patterns, displacement of fish, intraspecific aggression, reproductive pairing-spawning success, predator-prey interactions, food web dynamic alternations, larvae disbursement, and settlement (McLeay et al. 1987; Bash et al. 2001; Utne-Palm 2002; Suttle et al. 2004; Muck 2010; Chapman et al. 2014). However, there is a knowledge gap in our overall understanding regarding the relationship between increased sedimentation and behavioral effects (including sensory capabilities, motivation state) on non-salmonids, various migratory species, lotic species, larvae, and fish communities in particular involving the examination of species utilizing various levels of the water column and various life stages for a species that would reside in areas with periodic or chronic sediment loads.

There are relatively few studies that document in situ the ability of fish to avoid suspended sediment plumes and 
dredge activity areas and the prevalence of reduced exposure times as a result. Carlson et al. (2001) documented the behavioral responses of salmonids to dredging activities in the Columbia River using hydroacoustics. During dredging operations, out-migrating salmon smolt (Oncorhynchus spp., likely fall chinook salmon (O. tshawytscha) and coho salmon (O. kisutch)) behavioral responses ranged from (1) salmon orienting to the channel margin move inshore when encountering the dredge, (2) most out-migrating salmon passing inshore moved offshore upon encountering the discharge plume, and (3) out-migrating salmon were observed to assume their prior distribution trends within a short time after encountering both the dredging activity and dredge plume (as cited in Carlson et al. 2001). In artificial streams, previously unexposed fish juvenile chinook salmon showed a preference of $(80 \%)$ for clear water $(0 \mathrm{mg} / \mathrm{L}$ suspended sediment) in contrast to suspended sediment levels $>76 \mathrm{mg} / \mathrm{L}$, and generally avoiding all sediment levels $>20 \mathrm{mg} / \mathrm{L}$ (Birtwell 1999). In contrast, subadult white sturgeon (Acipenser transmontanus) rates of movement, depths, and diel patterns showed little change in response to hopper dredge disposal activities (Parsley et al. 2011). Overall though, volitional fish movement, whether avoidance or displacement and in a few cases preference, will depend upon the "perceived" options available in the water body and an individual's motivation state during elevated suspended sediment loads or dredging activity.

\subsection{Foraging and predator-prey interactions}

Depending on the foraging strategy of a species, direct exposure to high levels of suspended sediment can disrupt foraging activities or decrease foraging efficacy. The increased turbidity can cause changes in feeding behavior of the fish for the simple reason that the prey may be less visible (Ward 1992). Turbidity, due to the scattering of light, can increase or decrease the contrast between prey and the water column. In the case of some fish larvae, their visual detection of prey increases due to the less inference from light scattering (Utne-Palm 2002). In addition, the protection of larvae from large predators increases from the decreased ability of large visual predators. Thus, in certain cases, turbid environments may offer some benefits for certain species and size groups of fish (planktivores and fish larvae) (Utne-Palm 2002). More commonly though, sedimentation effects on freshwater fish can be graded out by habitat, or life history traits. For example, as sediment and deposited sediments increased, feeding behavior (defined as feeding rate, a reaction distance to food item) decreased in turbidity-tolerant [e.g., northern pike (Esox lucius) and largemouth bass (Micropterus salmoides)], moderately intolerant [e.g., chinook salmon, rainbow trout
(O. mykiss)], and intolerant species [e.g., brook trout (Salvelinus fontinalis)] (Chapman et al. 2014).

Similar to Chapman et al. (2014), Sullivan and Watzin (2010) found that fish of different life history styles, in this case foraging guilds, have varying tolerances to suspended sediment loads. For example, pumpkinseed (Lepomis gibossus, omnivores) showed no significant difference in condition (as measured by Fulton's K Factor) over sediment aggradation (slight, moderate, and severe) or time (14 days) (Sullivan and Watzin 2010). Olsen et al. (1973) reported that rainbow trout feeding activity drops sharply when turbidity surpasses 70 Jackson turbidity units (JTU), or less than $500 \mathrm{ppm}$ by weight for most sediment sources (Noggle 1978). It should be mentioned that the majority of the reviewed literature focuses on species that forage near the surface or within the water column; however, elevated turbidity concentrations can affect the ability of fish to forage on benthic organisms. Sullivan and Watzin (2010) showed that white suckers (Catostomus commersonii) and creek chubs (Semotilus atromaculatus) experienced a higher mortality compared with pumpkinseed under "severe" sediment aggradation conditions over 28 days. Similarly, Florida pompano (Trachinotus carolinus) had reduced foraging success on bean clams (Donax variabilis) and mole crabs (Emerita talpoida) with increased turbidity (Manning et al. 2013). These results indicate that opportunistic species feeding in several sections of the water column may be more resilient to suspended sediments than more specialized trophic groups (Sullivan and Watzin 2010). These findings indicate that fish foraging success is largely dependent upon their sensory capabilities and adaptive strategies.

Several studies, e.g., Gregory (1993), Gregory and Northcote (1993), Utne-Palm (1999), Bonner and Wilde (2002), Horppila et al. (2004), Rowe et al. (2003), and Shoup and Wahl (2009) provide insightful information regarding the effects of TSS on predator-prey interactions. For example, Gregory (1993), Gregory and Northcote (1993) found that a turbidity threshold of $200 \mathrm{mg} / \mathrm{L}$ could reduce dredge-induced salmonid prey-predator reaction changes. Miner and Stein (1996) also reported "changes in predator avoidance," and specifically, reaction distance declined as turbidity increased. Turbidity levels as low as 20 NTU can reduce the overall efficacy of foraging and prey captures in adult and juvenile salmonids (Berg 1982; Bash et al. 2001; Madej et al. 2007), and according to Kemp et al. (2011), other species have had similar effects. However, other studies have indicated that juvenile coho, steelhead, and chinook foraging in slightly to moderately turbid waters (Sigler et al. 1984; Gregory 1988; Bash et al. 2001), and that prey consumption is not significantly affected in species that are adapted to more turbid waters (Kemp et al. 2011). 


\subsection{Fish physiology and direct physical stress}

The deleterious effects of suspended sediments directly on fish physiology are well documented. While increases in sediment load (both suspended and deposited) can have a negative effect across multiple scales of fish communities, from individual level (e.g., spawning success and fry emergence) to the system level (e.g., decreased species richness) (Chapman et al. 2014), the direct cause-effect pathways linking the impacts of sediment loads directly to injury and/or physiological stress is still ambiguous (Nightingale and Simenstad 2001). Rich (2010) provides an informative table of exposure concentrations, durations, and associated mortality.

\subsubsection{Sublethal stress}

In order to determine suspended sediment effects, Berli et al. (2014) examined metabolic parameters associated with swimming performance in juvenile trout, comparing hatchery strains of rainbow trout (RBT) and a strain of brown trout (Salmo trutta; BNT), using three concentrations of calcium carbonate. In general, as turbidity increased, swimming performance decreased, and RBT strains experienced a higher degree of impairment in swimming performance than BNT (Berli et al. 2014). For the groups, indicators of aerobic metabolism (i.e., citrate synthase activities and glucose levels) were elevated, while those of anaerobic metabolism (i.e., plasma lactate and LDH activities) were depressed (Berli et al. 2014). Based on these results, Berli et al. (2014) suggested that acute exposures to environmentally relevant turbidities generated by fine suspended sediment may cause a reduced $U_{\text {crit }}$ and that these changes may be related to changes in the utilization of aerobic and anaerobic pathways.

There are many environmental factors that are responsible in determining the magnitude of suspended sediment impact on salmonids including the following: duration and frequency of exposure, water temperature sediment toxicity, fish life stage and life history, particle angularity and size, sediment pulse magnitude and timing, physical condition of biota, and refugia/habitat availability and access (Bash et al. 2001; Muck 2010). Results indicate seasonal changes in the tolerance of salmonids to suspended sediment. For instance, metabolic oxygen demand increases as temperature increases, but water oxygen concentrations decrease (Muck 2010) and may decrease even more during dredging activities where organic material is re-suspended, i.e., associated oxygen requirements during decomposition. Excess suspended sediments can result in significant changes in behavior (Wedemeyer et al. 1984; Schreck et al. 1997; Sutherland 2003), such as feeding (e.g., Berg and Northcote 1985), predator avoidance (Miner and Stein
1996), and modified movement or migration (Carlson et al. 2001); reduced food availability (Kemp et al. 2011); gill trauma (Goldes et al. 1988; Newcombe and MacDonald 1991; Beussink 2007); and increased metabolic costs or energy expenditure shifts (Schreck 2010).

\subsubsection{Stressor duration, tolerance, and lethality}

The effects of suspended sediments on fish vary across species and depend upon several factors, including the life history and species-specific characteristics (e.g., sediment tolerance), the duration of exposure, frequency of events, the type of sediment (including angularity). Generally, benthic species are more tolerant to suspended sediment than pelagic species (Rogers 1969; Sherk et al. 1974; Noggle 1978). Also, closely related species can express different stress levels at similar exposures, e.g., chum salmon $(O$. keta) fry exposed to suspended sediment concentrations of 28 and $55 \mathrm{~g} / \mathrm{L}$ resulted in $50 \%$ mortality after $96 \mathrm{~h}$ (Smith 1978), whereas the same mortality rate was expressed at lower concentrations $1.2-35 \mathrm{~g} / \mathrm{L}$ over the same duration for coho, chinook, and steelhead salmon (Noggle 1978). Notably, threshold effects can result in higher mortalities; e.g., rainbow trout in the Powder River (Oregon) died within 3 weeks when the concentration of suspended sediment reached 1000-2500 ppm (Campbell 1954). Table 1 reports suspended sediment mortality effects for several other species. In addition to mortality effects, suspended sediment can impact other aspects of fish behavior and physiology, including growth rate (e.g., whitetail shiner, Cyprinella galactura) (Sutherland 2003) or feeding behavior [e.g., rainbow trout (Olsen et al. 1973; Noggle 1978)]. Berry et al. (2003) provide much more detail regarding suspended sediments and effects on fish species.

Understanding the interactions between stressors and a species' life history and physiology can help natural resource managers design management actions that mitigate the effects of the stressor, or assist with the development of therapeutants (Schreck et al. 2001). Given the ebb and flow of disturbance regimes in nature, fish have developed trade-offs for dealing with stress that, in general, affects reproductive fitness by altering gametic or progenic quality (Schreck et al. 2001). For example, disturbance, including handling, can affect the timing of reproduction: in rainbow trout disturbance delays reproduction, whereas tilapia (Oreochromis niloticus) either accelerate or completely inhibit reproduction depending on which maturational stage is occurring during the disturbance event (Schreck et al. 2001).

There is currently a lack of holistic-based studies that can identify how the stressors impact fish across scales (Schreck 2010), which makes understanding the total 
Table 1 Effects of suspended sediment levels by species

\begin{tabular}{|c|c|c|c|c|c|c|}
\hline Common Name & Species & Sediment & Concentration & Duration & $\begin{array}{l}\text { Mortality } \\
(\%)\end{array}$ & References \\
\hline Carp & Cyprinus spp. & Montmorillonite clay & $175,000-225,000 \mathrm{ppm}$ & days & 100 & Wallen 1951 \\
\hline Cunner & Tautogolabrus adspersus & Various sediments & $3-300 \mathrm{~g} / \mathrm{L}$ & $12-48 \mathrm{~h}$ & 50 & Noggle 1978 \\
\hline $\begin{array}{l}\text { Fourspine } \\
\text { stickleback }\end{array}$ & Apeltes quadracus & Various sediments & $3-300 \mathrm{~g} / \mathrm{L}$ & $12-48 \mathrm{~h}$ & 50 & Noggle 1978 \\
\hline Golden shiner & Notemigonus crysoleucas & Montmorillonite clay & $175,000-225,000 \mathrm{ppm}$ & days & 100 & Wallen 1951 \\
\hline Mummichog & Fundulus heteroclitus & $\begin{array}{l}\text { Estuary sediment/ } \\
\text { fuller's earth }\end{array}$ & $24-169 \mathrm{~g} / \mathrm{L}$ & $24 \mathrm{~h}$ & $10-90$ & Noggle 1978 \\
\hline Mummichog & Fundulus heteroclitus & Various sediments & $3-300 \mathrm{~g} / \mathrm{L}$ & $12-48 \mathrm{~h}$ & 50 & Noggle 1978 \\
\hline $\begin{array}{l}\text { Sheepshead } \\
\text { minnow }\end{array}$ & Cyprinodon variegatus & Various sediments & $3-300 \mathrm{~g} / \mathrm{L}$ & $12-48 \mathrm{~h}$ & 50 & Noggle 1978 \\
\hline Shiner perch & Cymatogaster aggregata & Bentonite Clay & $0.3-0.9 \mathrm{~g} / \mathrm{L}$ & 10 days & $10-50$ & $\begin{array}{l}\text { Peddicord et al. 1975; } \\
\text { Noggle } 1978\end{array}$ \\
\hline Spot & Leiostomus xanthurus & $\begin{array}{l}\text { Estuary sediment/ } \\
\text { fuller's earth }\end{array}$ & $13-111 \mathrm{~g} / \mathrm{L}$ & $24 \mathrm{~h}$ & $10-90$ & Noggle 1978 \\
\hline Striped bass & Morone saxatilis & Bentonite Clay & $1-5 \mathrm{~g} / \mathrm{L}$ & 10 days & $10-50$ & $\begin{array}{l}\text { Peddicord et al. 1975; } \\
\text { Noggle } 1978\end{array}$ \\
\hline Striped killifish & Fundulus majalis & $\begin{array}{l}\text { Estuary sediment/ } \\
\text { fuller's earth }\end{array}$ & $1-5 \mathrm{~g} / \mathrm{L}$ & $24 \mathrm{~h}$ & $10-90$ & Noggle 1978 \\
\hline White perch & Morone americana & $\begin{array}{l}\text { Estuary sediment/ } \\
\text { fuller's earth }\end{array}$ & $3-39 \mathrm{~g} / \mathrm{L}$ & $24 \mathrm{~h}$ & $10-90$ & Noggle 1978 \\
\hline Zebrafish & Danio rerio & Inorganic limestone & $4.8 \mathrm{~g} / \mathrm{L}$ & $4 \mathrm{~h}$ & 100 & Reis 1969 \\
\hline
\end{tabular}

impact of stress on fish populations difficult. Stress response cycles vary not only with the duration and severity of the stress response, but also with the developmental stage of individuals as well as across different physiological, genetic, or reproductive processes. Resisting a stressor and mounting a stress response are energetically costly processes, and the energy required to deal with the stress must be reallocated (generally toward increased oxygen consumption and metabolic rate to deal with the event) (Barton and Schreck 1987; Contreras-Sanchez et al. 1998; McCormick et al. 1998; Muck 2010). If this reallocation reduces energy for reproduction, then there can be population-level consequences. Both the nature of a stressor and its severity can affect fish reproduction in many different ways: for example, evading predators (i.e., an emergency response) or coping with resource limitations due to higher densities are both stressors, but both involve allocating and re-budgeting energy differently, both of which can have impacts at the population level (Schreck 2010); for example, energy is diverted from reproduction to heat-shock protein production (Krebs and Loeschcke 1994; Loeschcke et al. 2013).

Reproduction can be affected by stress in various ways, depending upon when it is experienced in the life cycle and the severity and duration (Schreck 2010). Increased suspended sediment loads can cause physiological, bioenergetic, and behavioral alterations (e.g., delays in spawning) which may in turn affect egg quantity or quality and embryo development (Bash et al. 2001). For example, stress from suspended solids impacts eggs and alevins more than adults (Muck 2010), but other sources of stress can impact ovulation or inhibit reproduction, which can impact both gamete quality and fecundity. Acute stress can have several effects on the reproduction of fish, including reducing egg size and delaying ovulation in females, reducing sperm counts in males, and lowering survival rates for offspring from stressed fish (Campbell et al. 1992), as well as significantly altering relative fecundity, particularly when compared to non-stressed individuals (Contreras-Sánchez et al. 1998). Cumulative stress can also impact reproduction [e.g., chronic confinement stress reduced egg size in rainbow trout and significantly lowered survival rates for progeny from both stressed brown trout and rainbow trout compared to progeny from unstressed controls (Campbell et al. 1994)]. Stress can also impact nutritional quality, which has been correlated with reproductive success [e.g., in wild cod (Gadus morhua) lower fecundity resulted from poorer nutritional condition (Lambert and Dutil 2000; Lambert et al. 2000; Schreck 2010)].

Stress induced by suspended sediments can also have impacts at the community level (Waters, 1995), including alterations in habitat (Allan et al. 1997), community diversity and productivity (Dudgeon 2000; Sullivan et al. 
2006), and the relative abundance of spawning guilds (Sutherland et al. 2002; Sullivan and Watzin 2010). Further, specialized foragers, such as white suckers, tend to be negatively affected more during sedimentation events, particularly when they are longer in duration, indicating that opportunistic species that feed across the water column may be more resilient to sedimentation than more specialized trophic groups (Sullivan and Watzin 2010). However, the mechanisms responsible for these patterns are complex and still not fully understood (Sullivan and Watzin 2010). In cases where streams are aggraded in patchy distributions, fish can often avoid higher sediment concentrations (Sullivan and Watzin 2010), but if the spatial distribution of suspended sediments is more uniform, then adverse effects via habitat alterations may be spread across multiple life stages (e.g., adults, nest building, egg development, and fry feeding) (Newcombe and Jensen 1996; Galbraith et al. 2006).

Several studies have found that exposure of fish to suspended solids can elicit a primary stress responses (PSR) by increasing both circulating and whole blood cortisol concentrations and levels, respectively (Redding et al. 1987; Humborstad et al. 2006; Sutherland et al. 2008; Rich 2010). There are fewer studies on the secondary stress responses (SSR) in fish exposed to SS and turbidity due to dredging, although three laboratory-based studies were reported in Rich (2010). Types of dredge-related studies conducted where tertiary stress responses (TSR) were used as endpoints consisting of seven field-based and seven laboratory-based studies (Rich 2010). It would seem an important avenue for further research given that the stress hormones, induced by PSR, can affect every organ and function of the body via SSR (Rich 2010). Changes in blood constituents, heart rate, metabolism, and osmoregulation are examples of SSR (Rich 2010). If the body is not able to re-equilibrate from the SSR then TSR result, e.g., lowered resistance to disease, slowed growth rate, and changes in behavior (e.g., avoidance) (Rich 2010).

In most estuaries, average concentrations of total suspended matter can range from a few $\mathrm{mg} / \mathrm{L}$ to several tens of $\mathrm{mg} / \mathrm{L}$, with the higher concentrations occurring near the benthic layer in areas re-suspension (Auld and Schubel 1978). However, during short-term episodic events, like dredging or spoil disposal, concentrations may be greater than several thousand $\mathrm{mg} / \mathrm{L}$, particularly in the regions nearest the source of the event. Laboratory studies have indicated that there is a complex set of interactions among species, life stage, concentration, and duration. For example, survival is reduced in larval striped bass and yellow perch (Perca flavescens) during 48- to 96-h exposures of $2500 \mathrm{mg} / \mathrm{L}$, but American shad are less tolerant (an exposure of $>100 \mathrm{mg} / \mathrm{L}$ for the same duration reduced survival); concentrations of over $1000 \mathrm{mg} / \mathrm{L}$ affected the hatching success of white perch and striped bass, but lower concentrations had no effect (Auld and Schubel 1978). In another study, when Pacific herring (Clupea pallasi) were exposed to concentrations of $250-500 \mathrm{mg} / \mathrm{L}$ for the same duration, self-aggregation of the eggs led to both lethal and sublethal impacts (Griffin et al. 2009). However, Kiørboe et al. (1981) reported that no impacts were discovered on Atlantic herring ( $C$. harengus) eggs when they were exposed to $5-300 \mathrm{mg} / \mathrm{L}$ at different stages of embryonic development.

A recent review of the biological effects of suspended sediments on fish and shellfish was conducted by Wilber and Clarke (2001) (Berry et al. 2003). Berry et al. (2003) synthesized the results of studies that report the doseresponse relationships of estuarine aquatic organisms to suspended sediments and then related those findings to sediment conditions associated with dredging projects. Suspended sediment effects on invertebrates include: direct impacts due to abrasion, interference with respiration and ingestion by clogging of filtration mechanisms, and in extreme cases mortality from smothering and burial (Berry et al. 2003). EIFAC (1965) reported harmful levels of solids for Daphnia (Daphnia spp.): kaolinite at $102 \mathrm{ppm}$, montmorillonite at $82 \mathrm{ppm}$, charcoal at $82 \mathrm{ppm}$, and pond sediment at $1458 \mathrm{ppm}$ (Bash et al. 2001). The distribution of infaunal and epibenthic species be impacted indirectly through light attenuation affecting feeding efficiency, behavior (avoidance and drift), and habitat alteration occurring from changes in the composition of substrate (Donahue and Irvine 2003; Waters 1995; Zweig and Rabeni 2001; Berry et al. 2003). Increases in suspended sediments (e.g., $120 \mathrm{mg} / \mathrm{L}$ ) can result in increased drift, significantly altering the distribution of benthic invertebrates in streams (Herbert and Merkens 1961; Berry et al. 2003). Both the duration and degree of exposure (i.e., TSS) are important factors to consider with regard to determining the effects on aquatic organisms (Berry et al. 2003). Waters (1995) considers the effects of increased deposition of sediments on benthic invertebrates as one of the most important concerns within the sediment pollution issue, especially with regard to the dependence of freshwater fisheries on benthic productivity (Berry et al. 2003). Fine sediments, in suspension or when deposited, can negatively impact macrophytes (Yamada and Nakamura 2002; Kemp et al. 2011). Fish are also directly affected by fine sediment either in suspension or deposited on the substrate (Kemp et al. 2011). The suspended or deposited fine sediment can influence physiology and behavior, habitat availability, food supply, and ability to forage efficiently (Kemp et al. 2011). Some salmonid species move towards less turbid water (if available) after short-duration exposures (Berg and Northcote 1985; Kemp et al. 2011). 
In freshwater systems, sediment management can have both direct and indirect impacts on species throughout the food web (Kemp et al. 2011). Direct impacts of sediment can include invertebrate mortality (e.g., via smothering) (Kefford et al. 2010). Further, suspended sediments can reduce dissolved oxygen and alter the trophic structure, which can cause the following: a reduction in planktonic and periphytic food sources; increased stress levels which can reduce feeding, growth rates; increased energetic costs; and lower immune system response to viral and bacterial infections (Redding et al. 1987; Shaw and Richardson 2001; Sutherland and Meyer 2007). With respect to setting sediment targets using loadings as a metric, Kemp et al. (2011) compiled five main constraints for identifying meaningful thresholds for freshwater fish, which included dependencies on the catchment (Walling 1995), reaches (Collins and Walling 2007), sediments, taxa, and life stage. Briefly, setting sediment targets requires a holistic, systemlevel approach. Managing sediments requires consideration of hydrogeomorphic setting of both the watershed and reach, understanding the sediment properties of the target location (e.g., fine clays and silts versus organics; contaminated versus uncontaminated) and the species that are being affected, and what life stages of those species would be affected during the time of the management actions (Berry et al. 2003).

Teasing out the impacts of the interacting components of the above-mentioned constraints can be a significant challenge because not only can exposure impact species and life stages differently, but these impacts can occur at different levels within species/life stages (e.g., genetic, physiological, and reproductive,) and can occur at different exposures. For example, physiological stress [measured as an increase immunoreactive corticosteroid (IRC) levels] was reported for all three life stages of two species [spotfin chub (Erimonax monachus) and whitetail shiner] when exposed to $100 \mathrm{mg} / \mathrm{L}$ (Sutherland et al. 2008). These results indicate that moderate sediment levels (i.e., $100 \mathrm{mg} / \mathrm{L})$ can impact a species regardless of life stage. Similarly, Ayu (Plecoglossus altivelis) had a stress response (measured as changes in cortisol levels) response when it was exposed to concentrations of $200 \mathrm{mg} / \mathrm{L}$ for $3 \mathrm{~h}$ (Awata et al. 2011). Sediment size, shape, and composition have also been reported to impact freshwater fish (McLeay et al. 1987; Servizi and Gordon 1990; Servizi and Martens 1991; Lake and Hinch 1999; Bray 2000). Extremely angular and round sediments of more than $40 \mathrm{~g} / \mathrm{L}$ were shown to cause decreased white blood cell concentrations at 96-h exposures in juvenile coho salmon (Lake and Hinch 1999).

Low levels of sediment may result in sublethal and behavioral effects such as increased activity, stress, and emigration rates; loss of or reduction in foraging capability; reduced growth and resistance to disease; physical abrasion; clogging of gills; and interference with orientation in homing and migration (as cited in McLeay et al. 1987; Newcombe and MacDonald 1991; Barrett et al. 1992; Lake and Hinch 1999; Bash et al. 2001; Watts et al. 2003; Vondracek et al. 2003; Berry et al. 2003; Muck 2010). Sediment fluxes are critical components of aquatic systems, and their dynamics are multidimensional and complex (Berry et al. 2003; Muck 2010). Maintaining these fluxes requires an understanding of the natural temporal and spatial processes as well as any anthropogenic drivers that can impact the system. For example, seasonal flows resulting from spring snowmelt are natural mechanisms that can mobilize the bed and move silt and sand from the coarse substrate (Osmundson et al. 2002), whereas damcontrolled flows might remove these high flows and affect species dynamics [as in the case of the endangered Colorado pikeminnow (Ptychocheilus lucius) which occurs on the heavily damned Colorado river, and whose recruitment has decreased as a result of changes in sediment loads resulting from dam operations] (Osmundson et al. 2002).

The degree of fish population declines is usually associated with the quantity of "fines" within a stream ecosystem (Castro and Reckendorf 1995; Muck 2010). Particles with diameters less than $6.4 \mathrm{~mm}$ are generally defined as "fines" (as cited in Bjornn et al. 1977; Shepard et al. 1984; Hillman et al. 1987; Chapman 1988; Bjornn and Reiser 1991; Rieman and McIntyre 1993; Castro and Reckendorf 1995b; The Montana Bull Trout Scientific Group (MBTSG) 1998; Muck 2010). There are a variety of negative impacts pertaining to fine sediments in streams, including: (1) loss of habitat for macroinvertebrates, i.e., fish prey (Rabeni et al. 2005; Wood et al. 2005), (2) physiological stress and direct physical damage for both fishes and macroinvertebrates (Newcombe and MacDonald 1991; Sutherland and Meyer 2007), (3) reduction in or elimination of reproductive habitat for benthic and crevice spawning fishes (Burkhead and Jelks 2001; Sutherland 2007), and (4) reductions in the locating and capturing prey ability of fishes due to visual impairment (Barrett et al. 1992; Zamor and Grossman 2007; Hazelton and Grossman 2009). According to Hazelton and Grossman (2009), stream fishes can be harmed by fine sediments through several mechanisms including: (1) decreased prey availability, (2) direct physical harm (Berkman and Rabeni 1987), (3) the risk of increased predation (Miner and Stein 1996), and (4) lowered breeding success (Burkhead and Jelks 2001; Sutherland 2007). Biotic responses to suspended sediment as a stressor are complex because they are dependent on: (1) both direct and indirect ecological effects, (2) species life histories, (3) species traits and differential tolerances, and (4) availability of habitat patch refugia (Schwartz et al. 2011), with refugia area being 
affected by suspended sediment itself. For example, combinations of flow and TSS concentration can alter habitat for several species. At average monthly flows and TSS concentrations of $150 \mathrm{mg} / \mathrm{L}$, habitat for bluegill sunfish (Lepomis macrochirus) was reduced by half, whereas channel catfish (Ictalurus punctatus) and largemouth bass were affected similarly, but at concentrations of $200 \mathrm{mg} / \mathrm{L}$ and $100 \mathrm{mg} / \mathrm{L}$, respectively (Stuber et al. 1982; Kundell and Rasmussen 1995).

Species that utilize pools or littoral areas can be impacted at different turbidity levels [i.e., 90 JTU for creek chub, and 180 JTU for green sunfish (Lepomis cyanellus)] (Kundell and Rasmussen 1995). Identifying biotic response measures that correlate with sediment stressor gradients is problematic (Nietch et al. 2005; Schwartz et al. 2011), primarily because of the possible multiple stressors that can occur in human impacted watersheds, e.g., temperature, toxic pollutants, hydromodification, nutrient enrichment, habitat alteration, degraded riparian condition, and land cover changes (Wichert and Rapport 1998; Sutherland et al. 2002; Walters et al. 2003; Rashleigh 2004; Halse et al. 2007; Magner and Brooks 2008; Schwartz et al. 2011). It also illustrated that each species' traits and life history patterns have a unique relation to a suspended sediment environmental gradient, a gradient that is frequency and duration dependent (Schwartz et al. 2011). Suspended sediment can harm incubating fish eggs and fry (Cedarholm et al. 1982) and reduce the abundance of insect larvae, a food source for fish, by filling up the larvae's guts or nets with indigestible material (Hynes 1973; Ward 1992).

\subsection{Reproduction and epigenetics}

Effects of suspended sediment on spawning are found in the scientific literature, although they are mainly associated with the deleterious effects of sediment on gametes and embryo viability. There appears to be limited information in the scientific literature specifically looking at the sublethal effects of suspended sediment and associated environmental conditions, including exposure times and frequencies, regarding fish gametes and transgenerational implications. Sopinka et al. (2014) and Taylor et al. (2015) are some of the few examples of research that has been conducted with intergenerational implications in mind in this case regarding the effects of stress on salmon, albeit not involving suspended sediment. These studies demonstrate an important step toward thinking beyond just the physically observable direct effects on the organisms experiencing the effects and investigate the consequences on subsequent generations as well.

Research by Sopinka et al. (2012) examined the effects of pollution on gametes in wild-caught plainfin midshipman (Porichthys notatus), offering an insight into the possible effects on sperm characteristics, egg viability, and embryo survival. In another study, mercury exposure resulted in direct and indirect (transgenerational) effects on mummichog, specifically, reduced male survival, reduced ability of the offspring of exposed fish to reproduce successfully, and altered sex ratios (Matta et al. 1999). Yi et al. (2008) studied the concentrations of heavy metals in fish, invertebrates, sediment, and the water in the Yangtze River during 2006-2007 and found that heavy metals were 100-10,000 times higher in the sediment versus the water (Yi et al. 2008). The concentrations of heavy metals in the tissues of benthic invertebrates were relatively high also (Yi et al. 2008).

Reproductive behaviour and physiology can be negatively impacted by aquatic contaminants (Sopinka 2010). For instance, contaminant mobilization, contaminant leaching, bioaccumulation, and trophic transfer through the food web could occur because of the dredging or disposal of contaminated sediments, but the expression of the impacts thereof in exposed biota may have a lag time (Nightingale and Simenstad 2001). Gamete viability has been used previously as an indicator of reproductive endocrine disruption in fish (Kime and Nash 1999). Sopinka (2010) examined impacts on sperm in plainfin midshipman (Porichthys notatus) and round gobies (Neogobius melanostomus) and found that living in contaminated areas influenced gamete quality, specifically, greater proportions of dead eggs, greater testicular asymmetry, and shorter sperm heads. Sundberg et al. (2007) found a correlation between hepatic DNA adducts, via polychlorinated biphenyls (PCBs) and polycyclic aromatic hydrocarbons (PAHs), and pollutant burden in Northern pike and European perch (Perca fluviatilis) eggs revealing a threat to early life stages of fish. In Texas, the Houston Ship Channel (HSC) and upper Galveston Bay (GB) have sediments contaminated with dioxin (Yeager et al. 2010), and elevated dioxin concentrations have been detected in fish and crabs, i.e., Houston Ship Channel (HSC) in 1990 (Crocker and Young 1990; Yeager et al. 2010). Recent research has shown that the most significant dioxin reservoir is located in the bottom sediments (Suarez et al. 2005; Yeager et al. 2007, 2010). Sediment re-suspension, such as that associated with dredging activities, may re-introduce dioxins into the food chain (Yeager et al. 2010).

The impacts of dredging operations on aquatic organisms are still poorly understood. Some studies have shown that dredging contaminated sediments increases particulate-matter-associated contaminants in waters next to or near to the dredge, producing deleterious effects on species that occupy those areas. (e.g., Bellas et al. 2007; Bocchetti et al. 2008; Engwall et al. 1998; Sundberg et al. 2007; Sturve et al. 2005; Yeager et al. 2010). In order to prevent 
or minimize exposure of certain organisms to the effects of dredging activities, environmental windows (EWs) have been put in place in certain circumstances by regulatory and resource agencies (Suedel et al. 2012). EWs can be described as certain times when dredging and dredge material placement activities can be performed (NRC, 2001; Suedel et al. 2012). In contrast, other studies, e.g., Suedel et al. $(2012,2014)$ reported that there were no statistically significant effects on walleye (Sander vitreus) egg viability and hatching rates nor detrimental effects to fry exposed to SS exposures mimicking sediment re-suspension during dredging operations. However, the authors of the aforementioned study do mention that a slight reduction in egg viability occurred at $500 \mathrm{mg} / \mathrm{L} \mathrm{TSS}$ and that more research is needed regarding the potential sublethal effects in general. Further, Arambourou et al. (2014) noted that morphological abnormalities could appear after several generations of exposure. It is now known that some toxics, such as endocrine disruptors, can contribute to transgenerational developmental effects in aquatic organisms, such as in the Japanese rice fish, i.e., medaka (Oryzias latipes) (Gray et al. 1999; Zhang et al. 2008), leading to an increase in morphological (phenotypic) abnormalities in the offspring derived from the exposed parents (Arambourou et al. 2014).

It is known that sediments can serve as a carrier of many metals and toxic compounds, e.g., $\mathrm{Pb}, \mathrm{Cd}, \mathrm{Zn}, \mathrm{Cu}, \mathrm{Al}, \mathrm{Fe}$, Mn, Cr, and Ni (see e.g., Novotny and Chesters 1989; Kundell and Rasmussen 1995). Rivers contaminated by metals and organic substances have often been reported to be associated with an increased incidence of phenotypic defects, such as phenodeviation and fluctuating asymmetry (FA), particularly in invertebrates (Al-Shami et al. 2011; Bonada and Williams 2002; Groenendijk et al. 1998; Arambourou et al. 2014). Deposition of organic sediments can result in anaerobic conditions in rivers and streams by increasing the sediment oxygen demand (SOD) (Kundell and Rasmussen 1995). DNA damage in the male germ line has been linked to poor semen quality, low fertilization rates, impaired pre-implantation development, increased abortion, and an elevated incidence of disease in the offspring, including childhood cancer (as cited in Lewis and Aitken 2005). In addition, the cellular machinery that allows these cells to undergo complete apoptosis is progressively lost during spermatogenesis, so that the advanced stages of germ cell differentiation cannot be deleted, even though they may have proceeded some way down the apoptotic pathway (Gorczyca et al. 1993; McVicar et al. 2004). Consequently, the ejaculated gamete may exhibit genetic damage to both its nuclear and mitochondrial genomes (Sawyer et al. 2001, 2003). For instance, a study using zebrafish by Gosálvez et al. (2014) found that although sperm DNA fragmentation did not significantly influence oocyte fertilization capacity, it significantly and negatively affected later embryo development and overall reproductive success.

Many studies, e.g., Franklin and Mansuy (2010), Gillette et al. (2014), Christopher (2014), Gapp et al. (2014), and Missios et al. (2014), in mammals have shown that several stress-induced outcomes, such as DNA methylation and telomere length, can affect an individual's health, thereby impacting successive generations and population dynamics. Exposure to environmental chemicals and heavy metals such as BPA and Cd can negatively affect both male and female reproduction, alter behavior, and act as a carcinogen with short-term and long-term effects that typically occur through epigenetic mechanisms such as DNA methylation or noncoding RNAs, as has been observed in several species (e.g., Dhimolea et al. 2014; Mileva et al. 2014; Liu et al. 2014; Tellez-Plaza et al. 2014; Ray et al. 2014). Chemicals and heavy metals can cause epigenetic changes (e.g., DNA methylation) and genetic changes (e.g., telomere length) resulting in decreased gamete production and gamete quality, thereby negatively influencing population dynamics (Franklin and Mansuy 2010; Gillette et al. 2014). Also, these epigenetic marks and subsequent adverse effects can be transferred to the offspring through the gametes (Weigmann 2014; Wei et al. 2015; Gapp et al. 2014).

\subsection{Models}

Over the last decade, quantitative modeling has been used increasingly to determine the impact of dredging operations on fish (Clarke and Wilber 2000; Rich 2010), although there have been few focused modeling studies that examine the system-level impacts of dredging on fish populations. Existing models have been highly criticized as unreliable (Gregory et al. 1993; Clarke and Wilber 2000; Rich 2010), based on high levels of uncertainty associated with data used for model parameterizations, a lack of understanding of threshold values for minimum and maximum durations/concentrations below or above which impacts would not occur, subjectivity of expert opinion and index values used in model parameterizations, unrealistic sediment concentrations used in model scenarios, not including other environmental parameters such as water temperature, dissolved oxygen, particle size, and particle shape, and lack of field-based empirical studies on which to validate the models, without which it is difficult to derive the driver-stressor-response pathways (Newcombe and Jensen 1996; Burkhead and Jelks 2001; Rich 2010).

In order to quantitatively examine the biological and ecological impacts of dredging-created sedimentation, a model must provide the structure to quantify the extent and timing of mixing along the sediment-water interface. However, developing this type of model is complicated 


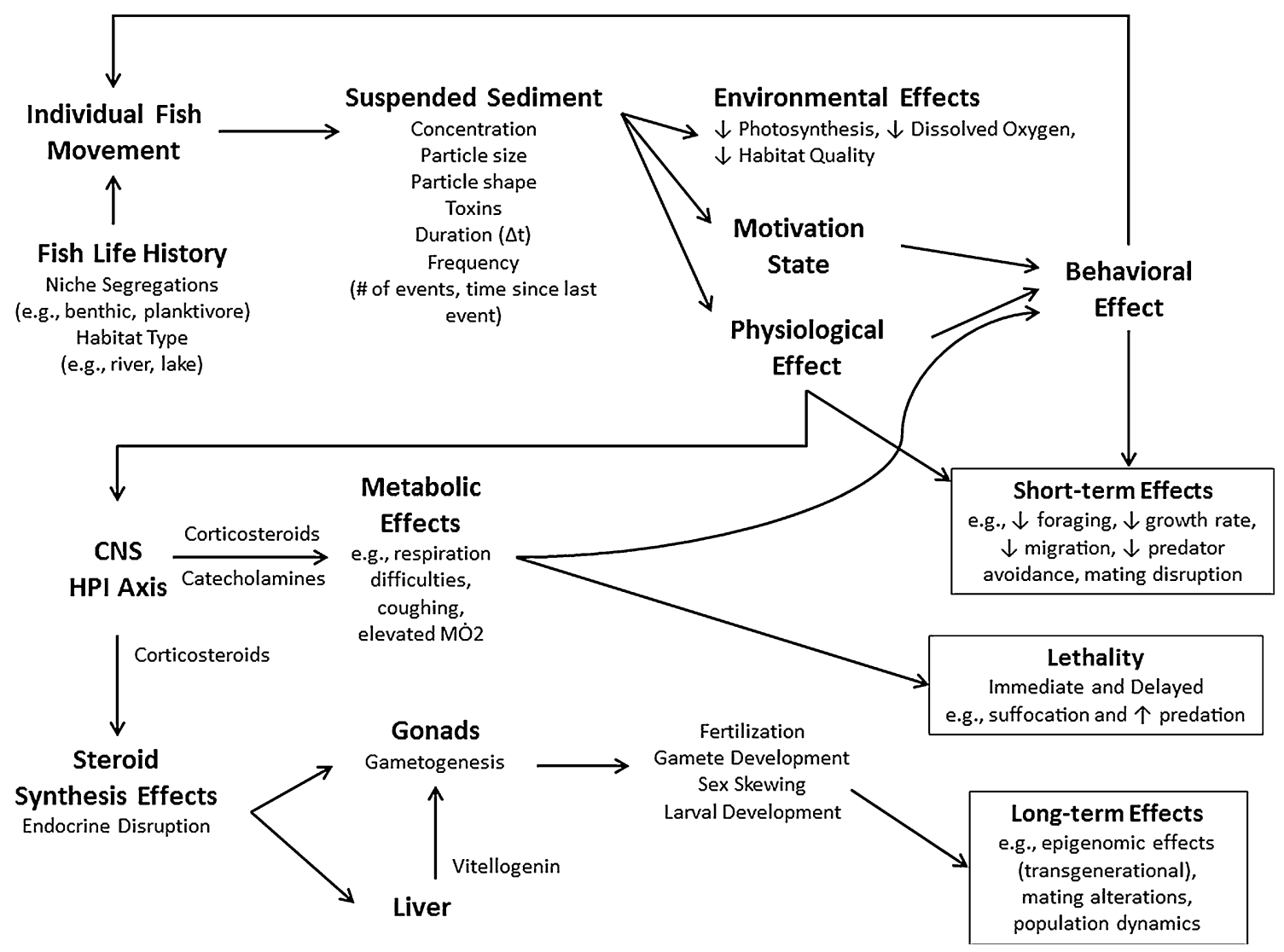

Fig. 1 Conceptual model of the effects of suspended sediments on fish

because it is difficult to resolve the issues on determining available sediment concentrations in the water column and how those concentrations will affect fish dynamics. In the Great Lakes, walleye eggs and larvae have been reported to be affected by sedimentation, but empirical datasets are largely lacking and extensive laboratory dose-response data are unavailable (Germano and Cary 2005), aside from a few more recent studies [e.g., Suedel et al. (2012, 2014)]. For salmonids, Lisle and Lewis (1992) developed a model focusing on survival of salmonid embryos, and they concluded that further research was needed to resolve the interactions among sediment transport, the inter-gravel environment, and embryo survival. Germano and Cary (2005) indicated that the fidelity and scale of available sedimentation data do not have fine enough resolution to predict impacts on the early stages of fish development. However, the effects of embeddedness have been described on hatching salmonids (Waters 1995) and this has helped with guidance to maximize salmonid production based on bed composition (Lotspeich and Everest 1981; Caux et al. 1997; Germano and Cary 2005). Further, there have been numerous studies that summarized both direct and indirect effects of sediments on other species (as summarized in Berry et al. 2003), but few have been synthesized into large-scale models. Dynamic energy budget (DEB) models (Noonburg et al. 1998; Nisbet et al. 2000) are designed to predict effects of stress on organism growth and survival, but have yet to be applied to dredging-created impacts on fish populations (Germano and Cary 2005).

Newcombe and McDonald (1991) proposed a doseresponse model, but the major problem with the proposed model was the simplicity, subjectivity of ranked responses, and lack of a well-defined mathematical model (Bray 2000). Gregory et al. (1993) had several criticisms of the Newcombe and McDonald (1991) model. First, there was a large variance in the data compiled by Newcombe and McDonald (1991), inherently reducing the model's predictive power of the model. A validation procedure was also lacking in the Newcombe and McDonald (1991) model for comparing the actual field observations with model predictions (Bray 2000). Another criticism of the Newcombe and McDonald (1991) model was that it did not have established threshold durations or concentrations beyond which impacts would not occur (Bray 2000). Gregory et al. (1993) pointed out that suspended sediment impacts will be variable not only with species, but also with life stage (Bray 2000), an aspect lacking in the Newcombe and McDonald (1991) model. Further, 
significant variables like water temperature and sediment size were not included in Newcombe and McDonald's (1991) model formulation, although such variables may play a major role in an organism's response to suspended sediments (Gregory et al. 1993).

In a subsequent modeling effort, Newcombe and McDonald (1993) reformulated the model with regard to the listing of ranked severity of ill effects, defining specific thresholds levels, behavioral effects, sublethal effects, and lethal effects (Bray 2000). Newcombe and McDonald (1993) also utilized data from a study by Servizi and Martens (1992) to show that impact on biological response for a particular species can vary by life stage. By pooling data from the scientific literature, from approximately 264 field studies, Newcombe and Jensen (1996) improved the SEV model in their last revision (see lethal and paralethal effects, concentrations and duration data for different species). Bray (2000) points out that definitions of appropriate recovery times associated with exposure of salmon species to SSC levels, i.e., thresholds, would be very useful for assessing biological impact from the Newcombe and Jensen (1996) model results, since this aspect was not accounted for in the model.

A clearer understanding of dredging, and consequently suspended sediments, effects to fish requires a synthesis of life history strategies, behavior and movement, physiology, organismal-level short-term effects, and ecological endpoints (i.e., lethality, epigenetic effects). Figure 1 illustrates the conceptual model of the effects of suspended sediments on fish that was developed based on the available literature.

\section{Conclusion}

Future modeling efforts are required to build upon the criticisms of model shortcomings and simplistic assumptions utilized in some of the past modeling efforts. Given recent advances in spatially explicit agent-based modeling, pattern-oriented modeling, and inverse modeling techniques, more realistic and informative models can be constructed and implemented that can project long-term effects (positive or negative) of sediment interactions with aquatic species. However, explicit regard to not only the organism itself but also transgenerational implications should be investigated and included in future modeling efforts.

Future efforts should focus on developing an understanding of whether environmental disturbances like dredging may lead to epigenetic changes, which can lead to population effects. Such research will be useful in decreasing uncertainty surrounding potential long-term effects of chemicals and heavy metals in the environment in both risk assessments and life cycle analyses. TSS and stress response information with regard to transgenerational and epigenetic implications is needed for more informed long-term management, as well as for assessing if cryptic, physiological non-observable manifestations of stress could threaten fish populations as well as species.

Acknowledgments This study was funded by the Dredging Operations and Environmental Research Program of the U.S. Army Corps of Engineers.

\section{Compliance with Ethical Standards}

Conflict of interest The authors declare that they have no conflicts of interest.

Open Access This article is distributed under the terms of the Creative Commons Attribution 4.0 International License (http://crea tivecommons.org/licenses/by/4.0/), which permits unrestricted use, distribution, and reproduction in any medium, provided you give appropriate credit to the original author(s) and the source, provide a link to the Creative Commons license, and indicate if changes were made.

\section{References}

Allan JD, Erickson DL, Fay J (1997) The influence of catchment land use on stream integrity across multiple spatial scales. Freshw Biol 37:149-161

Al-Shami SA, Che Salmah MR, Abu Assan A, Siti Azizah MN (2011) Fluctuating asymmetry of Chironomus spp. (Diptera: Chironomidae) larvae in association with water quality and metal pollution in Permatang Rawa River in the Juru River Basin, Penang. Malays Water Air Soil Poll 216:203-216

Arambourou H, Beisel J-N, Branchu P, Debat V (2014) Exposure to sediments from polluted rivers has limited phenotypic effects on larvae and adults of Chironomus riparius. Sci Total Environ 484:92-101

Auld AH, Schubel JR (1978) Effects of suspended sediment on fish eggs and larvae: a laboratory assessment. Estuar Coast Mar Sci 6:153-164

Awata S, Tsuruta T, Yada T, Iguchi K (2011) Effects of suspended sediment on cortisol levels in wild and cultured strains of ayu Plecoglossus altivelis. Aquaculture 314:115-121

Barrett JC, Grossman GD, Rosenfeld J (1992) Turbidity induced changes in reactive distance of rainbow trout. Trans Am Fish Soc 121:437-443

Barton BA, Schreck CB (1987) Metabolic cost of acute physical stress in juvenile steelhead. Trans Am Fish Soc 116:357-363

Bash J, Berman C, Bolton S (2001) Effects of turbidity and suspended solids on salmonids. Washington State Transportation Center (TRAC) Report No. WA-RD 526.1, November 2001, Olympia, WA, $92 \mathrm{pp}$

Bellas J, Ekelund R, Halldorsson HP, Berggren M, Granmo A (2007) Monitoring of organic compounds and trace metals during a dredging episode in the Göta Älv Estuary (SW Sweden) using caged mussels. Water Air Soil Poll 181:265-279

Berg L (1982) The effect of exposure to short-term pulses of suspended sediment on the behavior of juvenile salmonids. In: Hartman GF (ed) Proceedings of the carnation creek workshop: a ten-year review. Coordinating committee of the carnation creek watershed project, Nanaimo, Canada, pp 177-196 
Berg L, Northcote TG (1985) Changes in territorial, gill-flaring, and feeding behaviour in juvenile coho salmon (Oncorhynchus kisutch) following short-term pulses of suspended sediment. Can J Fish Aquat Sci 42:1410-1417

Berkman HE, Rabeni CF (1987) Effect of siltation on stream fish communities. Environ Biol Fish 18:285-294

Berli BI, Gilbert MJ, Ralph AL, Tierney KB, Burkhardt-Holm P (2014) Acute exposure to a common suspended sediment affects the swimming performance and physiology of juvenile salmonids. Comp Biochem Phys A Mol Integr Physiol 176:1-10. doi:10.1016/j.cbpa.2014.03.013

Berry W, Rubinstein N, Melzian B, Hill B (2003) The biological effects of suspended and bedded sediment (SABS) in aquatic systems: a review. US Environment Protection Agency, National Health and Environmental Health Effects Laboratory, Rhode Island, USA, p 58

Beussink ZS (2007) The effects of suspended sediment on the attachment and metamorphosis success of freshwater mussel parasitic life stages. Missouri State University, Springfield, Missouri, p 55

Birtwell IK (1999) The effects of sediment on fish and their habitat. Department of Fisheries and Oceans Canada, Canadian Stock Assessment Secretariat Research Document 99/139, ISSN 1480-4883, Ottawa, Canada, pp 34

Bjornn TC, Reiser DW (1991) Habitat requirements of salmonids in streams. In: Meehan WR (ed) Influences of forest and rangeland management on salmonid fishes and their habitats. American Fisheries Society Special Publication 19, Bethesda, pp $83-138$

Bjornn TC, Brusven MA, Molnau MP, Milligan JH, Klamt RA, Chacho E, Schaye C (1977) Transport of granitic sediment in streams and its effects on insects and fish. Bulletin 17. College of Forestry, Wildlife and Range Sciences, Moscow, Idaho, pp 43

Bocchetti R, Fattorini D, Pisanelli B, Macchia S, Oliviero L, Pilato F, Pellegrini D, Regoli F (2008) Contaminant accumulation and biomarker responses in caged mussels, Mytilus galloprovincialis, to evaluate bioavailability and toxicological effects of remobilized chemicals during dredging and disposal operations in harbour areas. Aquat Toxicol 89:257-266

Bonada N, Williams DD (2002) Exploration of the utility of fluctuating asymmetry as an indicator of river pollution using larvae of the caddisfly Hydropsyche morose (Trichoptera: Hydropsychidae). Hydrobiologia 481:147-156

Bonner TH, Wilde GR (2002) Effects of turbidity on prey consumption by prairie stream fishes. Trans Am Fish Soc 131(6):1203-1208

Bray BS (2000) Quantitative assessment of suspended sediment concentration on coho salmon in Freshwater Creek. Senior Thesis, Humboldt State University, Arcata, California

Burkhead NN, Jelks HL (2001) Effects of suspended sediment on the reproductive success of the tricolor shiner, a crevice-spawning minnow. Trans Am Fish Soc 130:959-968

Campbell HJ (1954) The effect of siltation from gold dredging on the survival of rainbow trout and eyed eggs in Powder River, Oregon. Oregon State Game Commission, Portland Oregon, p 3

Campbell PM, Pottinger TG, Sumpter JP (1992) Stress reduces the quality of gametes produced by Rainbow Trout. Biol Reprod 47:1140-1150

Campbell PM, Pottinger TG, Sumpter JP (1994) Preliminary evidence that chronic confinement stress reduces the quality of gametes produced by brown and rainbow trout. Aquaculture 120:151-169

Carlson TJ, Ploskey G, Johnson RL, Mueller RP, Weiland MA, Johnson PN (2001) Observations of the behavior and distribution of fish in relation to the Columbia River navigation channel and channel maintenance activities. Pacific Northwest National Laboratory, Richland, p 35
Castro J, Reckendorf F (1995) Effects of sediment on the aquatic environment: potential NRCS actions to improve aquatic habitat. Working Paper No. 6. Natural Resources Conservation Service, Oregon State University, pp 24. http://www.nrcs.usda.gov/wps/ portal/nrcs/detail/national/technical/?cid=nrcs143_014201 Accessed 08 April 2015

Caux P-Y, Moore DRJ, MacDonald D (1997) Ambient water quality guidelines (criteria) for turbidity, suspended and benthic sediments. Technical Appendix. Prepared for BC Ministry of Environment, Land and Parks, pp 146. http://www.env.gov.bc. ca/wat/wq/BCguidelines/turbidity/turbidity.html. Accessed 08 April 2015

Chapman DW (1988) Critical review of variables used to define effects of fines in redds of large salmonids. Trans Am Fish Soc 117:1-21

Chapman JM, Proulx CL, Veilleux MAN, Levert C, Bliss S, Andre ME, Lapointe NWR, Cooke SJ (2014) Clear as mud: a metaanalysis on the effects of sedimentation on freshwater fish and the effectiveness of sediment-control measures. Water Res 56:190-202

Christopher JC (2014) The bovine spermatozoal transcriptome and sire fertility. Dissertations and Master's Theses (Campus Access). Paper AAI3619432. http://digitalcommons.uri.edu/dis sertations/AAI3619432. Accessed 08 April 2015

Clarke DG, Wilber DH (2000) Assessment of potential impacts of dredging operations due to sediment resuspension. DOER Technical Notes (ERDC TN-DOER-E9). U.S. Army Engineer Research and Development Center, Vicksburg, Mississippi, pp 14

Coen LD (1995) A review of the potential impacts of mechanical harvesting on subtidal and intertidal shellfish resources. South Carolina Division of Natural Resources, Marine Resources Research Institute, James Island, South Carolina, pp 46

Collins AL, Walling DE (2007) Fine-grained bed sediment storage within the main channel systems of the Frome and Piddle catchments, Dorset, UK. Hydrol Process 21:1448-1459

Contreras-Sanchez WM, Schreck CB, Fitzpatrick MS, Pereira CB (1998) Effects of stress on the reproduction performance of rainbow trout (Oncorhynchus mykiss). Biol Reprod 58:439-447

Crocker PA, Young C (1990) Tetrachlorodibenzo-p-dioxins and dibenzofurans in edible fish tissue at selected sites in Arkansas, Louisiana, and Texas. U.S. Environmental Protection Agency, Region 6, Dallas, Texas, pp 87

Dhimolea E, Wadia PR, Murray TJ, Settles ML, Treitman JD, Sonnenschein C, Shioda T, Soto AM (2014) Prenatal exposure to BPA alters the epigenome of the rat mammary gland and increases the propensity to neoplastic development. PLoS One 9(7):99800

Donahue I, Irvine K (2003) Effects of sediment particle size composition on survivorship of benthic invertebrates from Lake Tanganyika, Africa. Archive fuer Hydrobiol 157:131-144

Dudgeon D (2000) The ecology of tropical Asian rivers and streams in relation to biodiversity conservation. Annu Rev Ecol Syst 31:239-263

Ellis MM (1936) Erosion silt as a factor in aquatic environments. Ecology 17:29-42

Engwall M, Naf C, Broman D, Brunstrom B (1998) Biological and chemical determination of contaminant levels in settling particulate matter and sediments-a Swedish river system before, during, and after dredging of PCB-contaminated lake sediments. Ambio 27:403-410

European Inland Fisheries Advisory Commission (EIFAC) Working Party on Water Quality Criteria for European Freshwater Fish (1965) Water quality criteria for European freshwater fish. Report on finely divided solids and inland fisheries. Int $\mathrm{J}$ Air Water Poll 9:151-168 
Fleming SW, Quilty EJ, Farahmand T, Hudson P (2005) Magnitudeduration based ecological risk assessment for turbidity and chronic temperature impacts: method development and application to millionaire creek. Prepared for the environmental quality section, environmental protection branch, British Columbia Ministry of Environment, Surrey. Prepared by Aquatic Informatics Inc., Vancouver, pp 56

Franklin TB, Mansuy IM (2010) Epigenetic inheritance in mammals: evidence for the impact of adverse environmental effects. Neurobiol Dis 39(1):61-65. doi:10.1016/j.nbd.2009.11.012

Galbraith RV, MacIsaac EA, Macdonald JS, Farrell AP (2006) The effect of suspended sediment on fertilization success in sockeye (Oncorhynchus nerka) and coho (Oncorhynchus kisutch) salmon. Can J Fish Aquat Sci 63:2487-2494

Gapp K, Jawaid A, Sarkies P, Bohacek J, Pelczar P, Prados J, Farinelli L, Miska E, Mansuy IM (2014) Implication of sperm RNAs in transgenerational inheritance of the effects of early trauma in mice. Nat Neurosci 17:667-669. doi:10.1038/nn.3695

Garcia MH (ed) (2008) Sedimentation engineering: processes, measurements, modeling, and practice. ASCE Manuals and Reports on Engineering Practice No. 110. American Society of Civil Engineers, Reston, VA, 1132 pp

Germano JD, Cary D (2005) Rates and effects of sedimentation in the context of dredging and dredged material placement. DOER Technical Notes Collection (ERDC TN-DOER-E19), U.S. Army Engineer Research and Development Center, Vicksburg, Mississippi, pp 12

Gillette R, Miller-Crews I, Nilsson EE, Skinner MK, Gore AC, Crews D (2014) Sexually dimorphic effects of ancestral exposure to vinclozolin on stress reactivity in rats. Endocrinology 155(10):3853-3866. doi:10.1210/en.2014-1253

Goldes SA, Ferguson HW, Moccia RD, Daoust PY (1988) Histological effects of the inert suspended clay kaolin on the gills of juvenile rainbow trout, Salmo gairdneri Richardson. J Fish Dis 11:23-33

Gorczyca W, Traganos F, Jesionowska H, Darzynkiewicz Z (1993) Presence of DNA strand breaks and increased sensitivity of DNA in situ to denaturation in abnormal human sperm cells: analogy to apoptosis of somatic cells. Exp Cell Res 207:202205

Gosálvez J, López-Fernández C, Hermoso A, Fernández JL, Kjelland ME (2014) Sperm DNA fragmentation in zebrafish (Danio rerio) and its impact on fertility and embryo viability-implications for fisheries and aquaculture. Aquaculture 433:173-182

Gray MA, Teather KL, Metcalfe CD (1999) Reproductive success and behaviour of Japanese medaka, Oryzias latipes exposed to 4-tertoctylphenol. Environ Toxicol Chem 18:2587-2594

Gregory RS (1993) Effect of turbidity on the predator avoidance behavior of juvenile chinook salmon (Oncorhynchus tshawytscha). Can J Fish Aquat Sci 50:241-246

Gregory RS (1988) Effects of turbidity on benthic foraging and predation risk in juvenile chinook salmon. In: Simenstad CA (ed) Effects of dredging on anadromous Pacific coast fishes. Workshop proceedings, September 8-9, 1988. Washington Sea Grant Program, University of Washington, Seattle

Gregory RS, Northcote TG (1993) Surface, planktonic, and benthic foraging by juvenile chinook salmon (Oncorhynchus tshawytscha) in turbid laboratory conditions. Can J Fish Aquat Sci 50:233-240

Gregory RS, Servizi JA, Martens DW (1993) Comment: utility of the stress index for predicting suspended sediment effects. N Am J Fish Manag 13:868-873

Griffin FJ, Smith EH, Vines CA, Cherr GN (2009) Impacts of suspended sediments on fertilization, embryonic development, and early larval life stages of the Pacific herring, Clupea pallasi. Biol Bull 216:175-187
Groenendijk D, Zeinstra LWM, Postma JF (1998) Fluctuating asymmetry and mentum gaps in populations of midge Chironomus riparius (Diptera: Chironomidae) from a metal contaminated river. Environ Toxicol Chem 17:1999-2005

Halse SA, Scanlon MD, Cocking JS, Smith MJ, Kay WR (2007) Factors affecting river health and its assessment over broad geographic ranges: the Western Australian experience. Environ Monit Assess 134:161-175

Hazelton PD, Grossman GD (2009) Turbidity, velocity and interspecific interactions affect foraging behaviour of rosyside dace (Clinostomus funduloides) and yellowfin shiners (Notropis lutippinis). Ecol Freshw Fish 18:427-436

Herbert DWM, Merkens JC (1961) The effect of suspended mineral solids on the survival of trout. Int J Air Water Pollut 5:46-55

Hillman TW, Griffith JS, Platts WS (1987) Summer and winter habitat selection by juvenile chinook salmon in a highly sedimented Idaho stream. Trans Am Fish Soc 116:185-195

Horppila J, Liljendahl-Nurminen A, Malinen T (2004) Effects of clay turbidity and light on the predator-prey interaction between smelts and chaoborids. Can J Fish Aquat Sci 61(10):1862-1870

Humborstad O-B, Jørgensen T, Grotmol S (2006) Exposure of cod Gadus morhua to resuspended sediment: an experimental study of the impact of bottom trawling. Mar Ecol Prog Ser 309:247-254

Hynes HBN (1973) The effects of sediment on the biota in running water. In: Fluvial processes and sedimentation: proceedings of a hydrology symposium. National Research Council, Ottawa, Canada, pp 653-663

Kefford BJ, Zalizniak L, Dunlop JE, Nugegoda D, Choy SC (2010) How are macroinvertebrates of slow flowing lotic systems directly affected by suspended and deposited sediments. Environ Pollut 158:543-550

Kemp P, Sear D, Collins A, Naden P, Jones I (2011) The impacts of fine sediment on riverine fish. Hydrol Process 25:1800-1821

Kime DE, Nash JP (1999) Gamete viability as an indicator of reproductive endocrine disruption in fish. Sci Total Environ 223:123-129

Kiørboe T, Frantsen E, Jensen C, Sørensen G (1981) Effects of suspended sediment on development and hatching of herring (Clupea harengus) eggs. Estuar Coast Shelf Sci 13:107-111

Krebs RA, Loeschcke V (1994) Costs and benefits of activation of the heat-shock response in Drosophila melanogaster. Funct Ecol 8:730-737

Kundell J, Rasmussen T (1995) Recommendations of the georgia board of regents scientific panel on evaluating the erosion measurement standard defined by the georgia erosion and sedimentation act. Proceedings 1995 georgia water resources conference. University of Georgia, Athens, Georgia, pp 211-217

Lake RG, Hinch SG (1999) Acute effects of suspended sediment angularity on juvenile coho salmon (Oncorhynchus kisutch). Can J Fish Aquat Sci 56:862-867

Lambert Y, Dutil J-D (2000) Energetic consequences of reproduction in Atlantic cod (Gadus morhua) in relation to spawning level of somatic energy reserves. Can J Fish Aquat Sci 57:815-825

Lambert Y, Dutil J-D, Ouellet P (2000) Nutritional condition and reproductive success in wild fish populations. In: Norberg B, Kjesbu OS, Taranger GL, Andersson E, Stefansson SO (eds) Proceeding of the 6th international symposium on the reproductive physiology of fish. Bergen, Norway, pp 77-84

Lewis SEM, Aitken RJ (2005) DNA damage to spermatozoa has impacts on fertilization and pregnancy. Cell Tissue Res 322:33-41

Liu Y, Yuan C, Chen S, Zheng Y, Zhang Y, Gao J, Wang Z (2014) Global and cyp19a1a gene specific DNA methylation in gonads of adult rare minnow Gobiocypris rarus under bisphenol a exposure. Aquat Toxicol 156C:10-16 
Loeschcke V, Krebs RA, Dahlgaard J, Michalak P (2013) Hightemperature stress and the evolution of thermal resistance in Drosophila. In: Bijlsma K, Loeschcke V (eds) Environmental stress, adaptation and evolution. Birkhäuser Verlag, $326 \mathrm{pp}$

Lotspeich FE, Everest FH (1981) A new method for reporting and interpreting textural composition of spawning gravel. U.S. Forest Service Research Note PNW-369

Madej MA, Wilzbach M, Cummins K, Ellis C, Hadden S (2007) The significance of suspended organic sediments to turbidity, sediment flux, and fish-feeding behavior. USDA Forest Service General Technical Report PSW-GTR-194, Albany, California, pp 383-385

Magner JA, Brooks KN (2008) Integrating sentinel watershedsystems into the monitoring and assessment of Minnesota's (USA) waters quality. Environ Monit Assess 138:149-158

Manning LM, Peterson CH, Fegley SR (2013) Degradation of surffish foraging habitat driven by persistent sedimentological modification caused by beach nourishment. Bull Mar Sci 89:83-106

Matta MB, Linse J, Cairncross C, Francendese L (1999) Early life stage and transgenerational effects of Aroclor 1268 and Mercury on fish: the LCP chemical site. National Oceanic and Atmospheric Administration, Seattle, WA and US EPA Region IV, Atlanta, GA, pp 80

McCormick SD, Shrimpton JM, Carey JB, O'Dea MF, Sloan KE, Moriyama S, Björnsson BTh (1998) Repeated acute stress reduces growth rate of Atlantic salmon parr and alters plasma levels of growth hormone, insulin-like growth factor I and cortisol. Aquaculture 168:221-235

McLeay DJ, Birtwell IK, Hartman GF, Ennis GL (1987) Responses of arctic grayling (Thymallus arcticus) to acute and prolonged exposure to Yukon placer mining sediment. Can J Fish Aquat Sci 44:658-673

McVicar CM, McClure N, Williamson K, Dalzell LH, Lewis SEM (2004) Incidence of Fas positivity and deoxyribonucleic acid double-stranded breaks in human ejaculated sperm. Fertil Steril 81:767-774

Mileva G, Baker SL, Konkle AT, Bielajew C (2014) Bisphenol-A: epigenetic reprogramming and effects on reproduction and behavior. Int J Environ Res Public Health 11(7):7537-7561

Miner JG, Stein RA (1996) Detection of predators and habitat choice by small bluegills: effects of turbidity and alternative prey. Trans Am Fish Soc 125:97-103

Missios P, Zhou Y, Guachalla LM, von Figura G, Wegner A, Chakkarappan SR, Binz T, Gompf A, Hartleben G, Burkhalter MD, Wulff V, Günes C, Sattler RW, Song Z, Illig T, Klaus S, Böhm BO, Wenz T, Hiller K, Rudolph KL (2014) Glucose substitution prolongs maintenance of energy homeostasis and lifespan of telomere dysfunctional mice. Nat Commun 5:4924. doi:10.1038/ncomms5924

Montana Bull Trout Scientific Group (MBTSG) (1998) The relationship between land management activities and habitat requirements of bull trout. The Montana Bull Trout Restoration Team, Helena, p 92

Muck J (2010) Biological effects of sediment on bull trout and their habitat-guidance for evaluating effects. Fish and Wildlife Service, Lacey, p 57

Newcombe CP (2003) Impact assessment model for clear water fishes exposed to excessively cloudy water. J Am Water Resour Assoc 39:529-544

Newcombe CP, Jensen JOT (1996) Channel suspended sediment and fisheries: a synthesis for quantitative assessment of risk and impact. N Am J Fish Manag 16:693-727

Newcombe CP, MacDonald DD (1991) Effects of suspended sediment on aquatic ecosystems. N Am J Fish Manag 11:72-82
Newcombe CP, MacDonald DD (1993) Utility of the stress index for predicting suspended sediment effects: response to comment. N Am J Fish Manag 13:873-876

Nichols G (1999) Sedimentology and stratigraphy. Blackwell Science, Oxford, pp 355

Nietch CT, Borst M, Schubauer-Berigan JP (2005) Risk management of sediment stress: a framework for sediment risk management research. Environ Manag 36:175-194

Nightingale B, Simenstad CA (2001) Dredging activities: marine issues. Washington State Transportation Center (TRAC) No. WA-RD 507.1, Olympia, Washington, pp 182

Nisbet RM, Muller EB, Lika K, Kooijman SALM (2000) From molecules to ecosystems through dynamic energy budget models. J Anim Ecol 69:913-926

Noggle CC (1978) Behavioral, physiological and lethal effects of suspended sediment on juvenile salmonids. MS Thesis, University of Washington, Seattle, Washington

Noonburg EG, Nisbet RM, McCauley E, Gurney WSC, Murdoch WW, de Roos AM (1998) Experimental testing of dynamic energy budget models. Funct Ecol 12:211-222

Novotny V, Chesters G (1989) Delivery of sediment and pollutants from nonpoint sources: a water quality perspective. J Soil Water Conserv 44:568-576

NRC (2001) A process for setting, managing, and monitoring environmental windows for dredging projects. Marine Board, Transportation Research Board, Special Report 262. National Research Council, National Academy Press, Washington, D.C., USA, pp 96

Olson WH, Chase DL, Hanson JN (1973) Preliminary studies using synthetic polymer to reduce turbidity in a hatchery water supply. Prog Fish Cult 35:66-73

Osmundson DB, Ryel RJ, Lamarra VL, Pitlick J (2002) Flowsediment-biota relations: implications for river regulation effects on native fish abundance. Ecol Appl 12:1719-1739

Parsely MJ, Popoff ND, Romine JG (2011) Short-term response of subadult white sturgeon to hopper dredge disposal operations. N Am J Fish Manag 31:1-11

Peddicord RK, McFarland VA, Belfiori DP, Byrd TE (1975) Effects of suspended solids on San Francisco Bay organisms. Physical impact study, appendix G, dredged disposal study, San Francisco Bay and Estuary, San Francisco District, US Army Corps of Engineers, San Francisco, July, pp. 158

Rabeni CF, Doisy KE, Zweig LD (2005) Stream invertebrate community functional responses to deposited sediment. Aquat Sci 67:395-402

Rashleigh B (2004) Relation of environmental characteristics to fish assemblages in the Upper French Broad River Basin, North Carolina. Environ Monit Assess 93:139-156

Ray PD, Yosim A, Fry RC (2014) Incorporating epigenetic data into the risk assessment process for the toxic metals arsenic, cadmium, chromium, lead, and mercury: strategies and challenges. Front Genet 5:201. doi:10.3389/fgene.2014.00201

Redding JM, Schreck CB, Everest FH (1987) Physiological effects on coho salmon and steelhead of exposure to suspended solids. Trans Am Fish Soc 116:737-744

Reid GK (1961) Ecology of inland waters and estuaries. Reinhold Publishing Corporation, New York, p 375

Reis PA (1969) Effects of inorganic limestone sediment and suspension on the eggs and fry of Branchydanio rerio. MA Thesis, DePauw University, Greencastle, Indiana

Rich AA (2010) Potential impacts of re-suspended sediments associated with dredging and dredged material placement on fishes in San Francisco Bay, California-Literature review and identification of data gaps. Army Corps of Engineers, San Francisco, California, p 259 
Rieman BE, McIntyre JD (1993) Demographic and habitat requirements for conservation of bull trout. United Stated Forest Service General Technical Report INT-302, Ogden, Utah, pp 42

Rogers BA (1969) Tolerance levels of four species of estuarine fishes to suspended mineral solids. MS Thesis, University of Rhode Island, Kingston, Rhode Island

Rowe DK, Dean TL, Williams E, Smith JP (2003) Effects of turbidity on the ability of juvenile rainbow trout, Oncorhynchus mykiss, to feed on limnetic and benthic prey in laboratory tanks. N Z J Mar Freshw Res 37:45-52

Ryder RA, Pesendorfer J (1989) Large rivers are more than flowing lakes: a comparative review. In: Dodge DP (ed) Proceedings of the international large river symposium. Canadian Special Publication of Fisheries and Aquatic Science,vol 106, pp 65-85

Sawyer DE, Roman SD, Aitken RJ (2001) Relative susceptibilities of mitochondrial and nuclear DNA to damage induced by hydrogen peroxide in two mouse germ cell lines. Redox Rep 6:182-184

Sawyer DE, Mercer BG, Wiklendt AM, Aitken RJ (2003) Quantitative analysis of gene-specific DNA damage in human spermatozoa. Mutat Res Fundam Mol Mech 529:21-34

Schreck CB (2010) Stress and fish reproduction: the roles of allostasis and hormesis. Gen Comp Endocr 165:549-556

Schreck CB, Olla BL, Davis MW (1997) Behavioural responses to stress. In: Iwama OK, Pickering AD, Sumpter JP, Schreck CB (eds) Fish stress and health in aquaculture. Society for Experimental Biology, Cambridge, pp 145-170

Schreck CB, Contreras-Sanchez W, Fitzpatrick MS (2001) Effects of stress on fish reproduction, gamete quality, and progeny. Aquaculture 197:3-24

Schwartz JS, Simon A, Klimetz L (2011) Use of fish functional traits to associate in-stream suspended sediment transport metrics with biological impairment. Environ Monit Assess 179:347-369

Servizi JA, Gordon RW (1990) Acute lethal toxicity of ammonia and SS mixtures to chinook salmon (Oncorhynchus tshawytscha). Bull Environ Contam Toxicol 44:650-656

Servizi JA, Martens DW (1991) Effect of temperature, season, and fish size on acute lethality of suspended sediments on coho salmon (Oncorhynchus kisutch). Can J Fish Manag Aquat Sci 48:493-497

Servizi JA, Martens DW (1992) Sublethal responses of coho salmon (Oncorhynchus kisutch) to suspended sediments. Can J Fish Manag Aquat Sci 49:1389-1395

Shaw EA, Richardson JS (2001) Direct and indirect effects of sediment pulse duration on stream invertebrate assemblages and rainbow trout (Oncorhynchus mykiss) growth and survival. Can J Fish Aquat Sci 58:2213-2221

Shepard BB, Leathe SA, Waver TM, Enk DM (1984) Monitoring levels of fine sediment within tributaries to Flathead Lake, and impacts of fine sediment on bull trout recruitment. In: Richardson F, Hamre RH (eds) Wild trout III. Federation of Fly Fishers and Trout Unlimited, Vienna, pp 146-156

Sherk JA, O'Connor JM, Neumann DA, Prince RD, Wood KV (1974) Effects of suspended and deposited sediments on estuarine organisms-phase II. Final report, September 17, 1970-December 31, 1973. Natural Resources Institute University, Maryland, College Park, Maryland, pp 299

Shoup DE, Wahl DH (2009) The effects of turbidity on prey selection by piscivorous largemouth bass. Trans Am Fish Soc 138(5):1018-1027

Sigler JW, Bjornn TC, Everest FH (1984) Effects of chronic turbidity on density and growth of steelheads and coho salmon. Trans Am Fish Soc 113:142-150

Smith DW (1978) Tolerance of juvenile chum salmon (Oncorhynchus keta) to suspended sediments. MS Thesis, University of Washington, Seattle, Washington
Sopinka NM (2010) Impact of environmental contaminants on sperm. MS Thesis. McMaster University, Hamilton, Canada

Sopinka NM, Fitzpatrick JL, Taves JE, Ikonomou MG, Marsh-Rollo SE, Balshine S (2012) Does exposure to aquatic pollution impact reproductive traits in a wild-caught intertidal fish? J Fish Biol 80:2374-2383

Sopinka NM, Hinch SG, Middleton CT, Hills JA, Patterson DA (2014) Mother knows best, even when stressed? Effects of maternal exposure to a stressor on offspring performance at different life stages in a wild semelparous fish. Oecologia 175:493-500

Stuber RJ, Gebhart G, Maughan OE (1982) Habitat suitability index models: Largemouth bass. US Fish and Wildlife Service, FWS/ OBS-82-10-16, Washington DC, p 32

Sturve J, Berglund A, Balk L, Broeg K, Böhmert B, Massey S, Savva D, Parkkonen J, Stephensen E, Koehler A, Förlin L (2005) Effects of dredging in Goteborg Harbor, Sweden, assessed by biomarkers in eelpout (Zoarces viviparus). Environ Toxicol Chem 24:1951-1961

Suarez MP, Rifai HS, Palachek RM, Dean KE, Koenig L (2005) Polychlorinated dibenzo-p-dioxins and dibenzofurans in Houston Ship Channel tissue and sediment. Environ Eng Sci 22:891-906

Suedel BC, Lutz CH, Clarke JU, Clarke DG (2012) The effects of suspended sediment on walleye (Sander vitreus) eggs. J Soils Sediments 12:995-1003

Suedel BC, Clarke JU, Lutz CH, Clarke DG, Godard-Codding C, Maul J (2014) Suspended sediment effects on walleye (Sander vitreus). J Gt Lakes Res 40:141-148

Sullivan SMP, Watzin MC (2010) Towards a functional understanding of the effects of sediment aggradation on stream fish condition. River Res Appl 26:1298-1314

Sullivan SMP, Watzin MC, Hession WC (2006) Influence of stream geomorphic condition on fish communities in Vermont, USA. Freshw Biol 51:1811-1826

Sundberg H, Hanson M, Liewenborg B, Zebuhr Y, Broman D, Balk L (2007) Dredging associated effects: maternally transferred pollutants and DNA adducts in feral fish. Environ Sci Technol 41:2972-2977

Sutherland AB (2003) Effects of excessive sedimentation on the growth and stress response of whitetail shiner (Cyprinella galactura) juveniles. In: Hatcher KJ (ed) Proceedings of the 2003 Georgia water resources conference, held April 23-24. University of Georgia, Institute of Ecology, Atlanta, Georgia, pp 4. http://hdl.handle.net/1853/48360. Accessed 08 April 2015

Sutherland AB (2007) Effects of increased suspended sediment on the reproductive success of an upland crevice spawning minnow. Trans Am Fish Soc 136:416-422

Sutherland AB, Meyer JL (2007) Effects of increased suspended sediment on growth rate and gill condition of two southern Appalachian minnows. Environ Biol Fish 80:389-403

Sutherland AB, Meyer JL, Gardiner EP (2002) Effects of land cover on sediment regime and fish assemblage structure in four southern Appalachian streams. Freshw Biol 47:1791-1805

Sutherland AB, Maki J, Vaughan V (2008) Effects of suspended sediment on whole-body cortisol stress response of two Southern Appalachian minnows, Erimonax monachus and Cyprinella galactura. Copeia 1:234-244

Suttle KB, Power ME, Levine JM, McNeely C (2004) How fine sediment in riverbeds impairs growth and survival of juvenile salmonids. Ecol Appl 14:969-974

Taylor JJ, Wilson SM, Sopinka NM, Hinch SG, Patterson DA, Cooke SJ, Willmore WG (2015) Are there intergenerational and population-specific effects of oxidative stress in sockeye salmon (Oncorhynchus nerka)? Comp Biochem Phys A 184:97-104 
Tellez-Plaza M, Tang WY, Shang Y, Umans JG, Francesconi KA, Goessler W, Ledesma M, Leon M, Laclaustra M, Pollak J, Guallar E, Cole SA, Fallin MD, Navas-Acien A (2014) Association of global DNA methylation and global DNA 6 hydroxymethylation with metals and other exposures in human blood DNA samples. Environ Health Perspect 122(9):946-954

U.S. EPA (2000) The quality of our nations waters. A summary of the national water quality inventory: 1998 report to congress. Office of Water, Washington DC. 841-S-00-001

U.S. EPA (2003) National water quality report to congress (305(b) report). http://www.epa.gov/OWOW/305b/. Accessed 08 April 2015

U.S. EPA (2006) Framework for developing suspended and bedded sediment (SABS) water quality criteria. Office of Water, Office of Research and Development. EPA-822-R-06-001 http://cfpub. epa.gov/ncea/cfm/recordisplay.cfm?deid $=164423$ Accessed 08 April 2015

U.S. Army Corps of Engineers (2015) U.S. waterway system: transportation facts and information. Navigation and Civil Works Decision Support Center. http://www.navigationdatacen ter.us/factcard/factcard.htm. Accessed 08 April 2015

Utne-Palm AC (1999) The effect of prey mobility, prey contrast, turbidity and spectral composition on the reaction distance of Gobiusculus flavescens to its planktonic prey. J Fish Biol 54:1244-1258

Utne-Palm AC (2002) Visual feeding of fish in a turbid environment: physical and behavioural aspects. Mar Freshw Behav Physiol 35:111-128

Vondracek B, Zimmerman JKH, Westra JV (2003) Setting an effective TMDL: sediment loading and effects of suspended sediment on fish. J Am Water Resour Assoc 39:1005-1015

Wallen IE (1951) The direct effect of turbidity on fishes. Bull Okla Agric Mech Coll 48:1-27

Walling DE (1995) Suspended sediment yields in a changing environment. In: Gurnell AM, Petts GE (eds) Changing river channels. John Wiley \& Sons, West Sussex, pp 149-176

Walters DM, Leigh DS, Bearden AB (2003) Urbanization, sedimentation, and the homogenization of fish assemblages in the Etowah River Basin, USA. Hydrobiologia 494:5-10

Ward N (1992) The problem of sediment in water for fish. Northwestern Ontario boreal forest management technical notes (TN-21). Ministry of Natural Resources, Ontario

Waters TF (1995) Sediment in streams: sources, biological effects, and control. American Fisheries Society Monograph 7, Bethesda, p 251

Watts CD, Naden PS, Cooper DM, Gannon B (2003) Application of a regional procedure to assess the risk to fish from high sediment concentrations. Sci Total Environ 314-316:551-565

Wedemeyer GA, McLeay JD, Goodyear CP (1984) Assessing the tolerance of fish and fish populations to environmental stress: the problems and methods of monitoring. In: Cairns WV, Hodson PV, Nriaqu JO (eds) Containment effects on fisheries. John Wiley and Sons, New York, pp 163-196

Wei Y, Schatten H, Sun QY (2015) Environmental epigenetic inheritance through gametes and implications for human reproduction. Hum Reprod Update 21(2):194-208

Weigmann K (2014) Lifestyle in the sperm: there is growing evidence that epigenetic marks can be inherited But what is the nature of the information they store and over how many generations do they prevail? EMBO Rep 15(12):1233-1237. doi:10.15252/ embr.201439759

Wichert GA, Rapport DJ (1998) Fish community structure as a measure of degradation and rehabilitation of riparian systems in an agricultural drainage basin. Environ Manag 22:425-443

Wilber D, Clarke D (2001) Biological effects of suspended sediments: a review of suspended sediment impacts on fish and shellfish with relation to dredging activities in estuaries. N Am J Fish Manag 21:855-875

Wood PJ (1997) Biological effects of fine sediments in the lotic environment. Environ Manag 21:203-217

Wood PJ, Toone J, Greenwood MT, Armitage PD (2005) The response of four lotic macroinvertebrate taxa to burial by sediments. Arch Hydrobiol 163:145-162

Yamada H, Nakamura F (2002) Effect of fine sediment deposition and channel works on periphyton biomass in the Makomanai River, northern Japan. River Res Appl 18:481-493

Yeager KM, Santschi PH, Rifai H, Suarez M, Brinkmeyer R, Hung CC, Schindler KJ, Andres M, Weaver EA (2007) Dioxin chronology and fluxes in sediments of the Houston Ship Channel, Texas: influences of non-steady state sediment transport and total organic carbon. Environ Sci Technol 41:52915298

Yeager KM, Brinkmeyer R, Rakocinski CF, Schindler KJ, Santischi PH (2010) Impacts of dredging activities on the accumulation of dioxins in surface sediments of the Houston Ship Channel, Texas. J Coast Res 26:743-752

Yi Y, Wang Z, Zhang K, Yu G, Duan X (2008) Sediment pollution and its effect on fish through food chain in the Yangtze River. Int J Sediment Res 23:338-347

Zamor RM, Grossman GD (2007) Turbidity affects foraging success of drift-feeding rosyside dace. Trans Am Fish Soc 136:167-176

Zhang Z, Hu J, Zhen H, Wu X, Huang C (2008) Reproductive inhibition and transgenerational toxicity of triphenyltin on Medaka (Oryzias latipes) at environmentally relevant levels. Environ Sci Technol 42:8133-8139

Zweig LD, Rabeni CF (2001) Biomonitoring for deposited sediment using benthic invertebrates: a test on 4 Missouri streams. J N Am Benthol Soc 20:643-657 